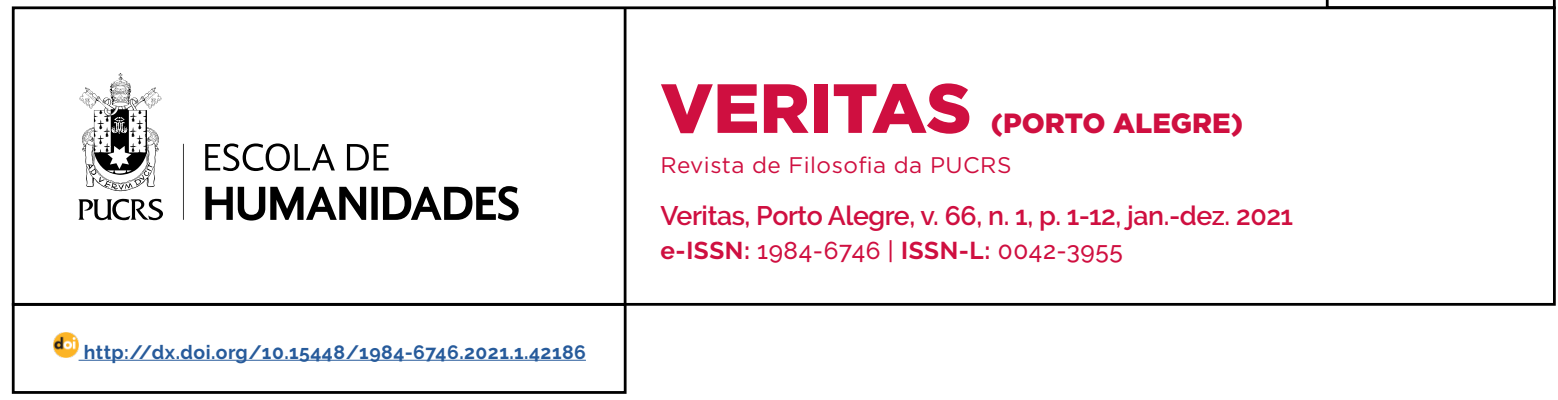

SEÇÃO EPISTEMOLOGIA \& FILOSOFIA DA LINGUAGEM

\title{
Dogmatism and Ampliative Inference
}

\author{
Dogmatismo e Inferência Ampliativa \\ Dogmatismo e Inferencia Ampliatival
}

\author{
Berit Brogaard ${ }^{1}$ \\ orcid.org/0000-0001-8712-0897 \\ brit@miami.edu
}

Received on: 12 nov. 2001.

Approved on: 15 nov. 2021. Published on: 27 dez. 2021

\begin{abstract}
The evidential role of experience in justifying beliefs has been at the center of debate in philosophy in recent years. One view is that experience, or seeming, can confer immediate (defeasible) justification on belief in virtue of its representational phenomenology. Call this view "representational dogmatism." Another view is that experience confers immediate justification on belief in virtue of its relational phenomenology. Call this view "relational dogmatism." The goal of this paper is to pit these two versions of dogmatism against each other in terms of their ability to account for ampliative, or non-deductive, inferential justification. I will argue that only the representational view can provide a plausible account of this type of justification.
\end{abstract}

Keywords: Ampliative inference. Disjunctivism. Phenomenal dogmatism. Skepticism. Transmission.

Resumo: O papel evidencial da experiência na justificação de crenças tem estado no centro dos debates filosóficos nos últimos anos. Uma concepção é que a experiência, ou a aparência, pode conferir justificação imediata (revocável) à crença em virtude de sua fenomenologia representacional. Chame essa proposta de "dogmatismo representacional". Outra concepção é que a experiência confere justificação imediata à crença em virtude de sua fenomenologia relacional. Chame essa proposta de "dogmatismo relacional". O objetivo deste artigo é contrastar essas duas versões de dogmatismo em termos de sua capacidade de explicar a justificação inferencial ampliativa ou não dedutiva. Argumentarei que apenas a concepção representacional pode fornecer uma explicação plausivel desse tipo de justificativa.

Palavras-chave: Inferência ampliativa. Disjuntivismo. Dogmatismo fenomenal. Ceticismo. Transmissão.

Resumen: El papel probatorio de la experiencia en la justificación de las creencias ha estado en el centro del debate de la filosofía en los últimos años. Un punto de vista es que la experiencia, o la apariencia, puede conferir una justificación inmediata (anulable) a la creencia en virtud de su fenomenología representacional. Llame a este punto de vista "dogmatismo representacional". Otro punto de vista es que la experiencia confiere una justificación inmediata a la creencia en virtud de su fenomenologia relacional. Llame a este punto de vista "dogmatismo relacional". El objetivo de este artículo es contrastar estas versiones del dogmatismo en términos de su capacidad para dar cuenta de la justificación inferencial ampliativa o no deductiva. Argumentaré que solo la concepción representacional puede proporcionar una explicación plausible de este tipo de justificación.

Palabras clave: Inferencia ampliativa. Disyuntivismo. Dogmatismo fenomenal. Escepticismo. Transmisión. 


\section{Introduction}

The evidential role of experience in justifying beliefs has been at the center of debate in philosophy in recent years. ${ }^{4}$ One view in this debate is that an experience (or a seeming) can confer immediate prima facie justification on belief in virtue of its representational phenomenology. Call this view "representational dogmatism."5 Another view is that experience can confer immediate justification on belief in virtue of its relational phenomenology. Call this view "relational dogmatism."6

Experience, here, comprises not just perceptual experience but all mental states with a cognitive or sensory phenomenology. Although many dogmatists restrict their view to perceptual experience, my focus here is on a version of the view that ascribes an evidential role in justifying beliefs to a wider range of mental states, such as perceptual experience, recollections, and intuitions.

Representational dogmatism presupposes a representational conception of perceptual experience. Defenders of representational views of experience hold that experience is fundamentally a matter of representing the world as being a certain way. If a perceptual experience represents the world as being a way that it is not, the experience is inaccurate, or non-veridical.

Relational dogmatism, by contrast, presupposes a relational account of experience, such as disjunctivism or related conceptions. On the disjunctivist conception, perceptual experience directly acquaints the perceiver with an external object and perceptible property instances. Perception is thus a success state. Non-veridical states are not perceptual states but "mere appearances" (MCDOWELL 1982: 386) or another mental state (FISH, 2009a, 2009b).

A common motivation for a disjunctivist conception of perceptual experience is that this conception is required to provide a plausible account of perceptual justification. If perceptual experience directly acquaints us only with intermediaries between us and the external world, then it's hard to see how we can have epistemic access to the external world.

Representational dogmatism gives defenders of representational views the tools needed to account for perceptual justification. While this virtue of representational dogmatism has been widely acknowledged in the philosophical literature, less has been written on how phenomenal and relational dogmatism compare when it comes to non-perceptual justification.?

The goal of this paper is to pit the two versions of dogmatism against each other with respect to their ability to account for ampliative, or non-deductive, inferential justification. I will argue that only representational dogmatism can provide a plausible account of this type of justification.

My plan is as follows. In section 2, I provide the details of relational dogmatism and show how this view avoids succumbing to skepticism about perceptual belief. In section 3, I argue that relational dogmatism runs into trouble when it comes to non-deductive inferential justification. Finally, in section 4, I outline the details of representational dogmatism and show that it can account for both perceptual and non-deductive inferential justification.

Before executing this plan, I should note that my primary focus here is on propositional justification rather than doxastic justification (see e.g., TURRI, 2010). To a first approximation, $\mathrm{S}$ has propositional justification for believing that $p$ just in case $S$ has an experience, belief, thought, or other mental state that provides evidential support for $p$. S has doxastic justification for her belief that $p$ just in case $\mathrm{S}$ believes that $p$. S has propositional justification for $p$, and $S$ 's belief that $p$ is properly based on S's propositional justification. Thus, where doxastic justification is something beliefs possess, propositional justification is something

\footnotetext{
4 E.g., McGrath (2013, 2018), Chudnoff (2013, 2018), McCain (2014, 2018), Siegel (2017).

5 This view is more commonly known as "dogmatism," "phenomenal dogmatism," and "phenomenal conservatism." For defenses of variants of representational (or content) dogmatism, see e.g., Chisholm (1966), Pollock (1986: 17), Pryor (2000), Huemer (2001, 2005, 2007), Silens (2008, 2013), Brogaard (2013a, 2017, 2018a), Chudnoff (2013, 2014a, 2018), Reiland (2015), McCain (2018).

6 For defenses of variants of relational dogmatism, see e.g., McDowell (1982), BonJour (1985, 1998, 2001, 2003), Fumerton (1995, 2009, 2016), McGrew (1995, 1998), Alston (2002), Leite (2008), Fish (2009a, 2009b). For discussion, see also Stoutenburg (2020).

7 For discussions of representational dogmatism and skepticism, see e.g. Pryor (2000) and Huemer (2001).
} 
subjects have for believing a proposition. Propositional justification is also sometimes referred to as a "warrant" or "evidence."

\section{The Skeptical Problem and Relational Dogmatism}

Relational dogmatism holds that experience confers immediate justification on belief in virtue of its relational phenomenology. A relational phenomenology is a relational, non-intentional, and non-judgmental form of awareness that directly acquaints a subject with a fact. We can articulate relational dogmatism in terms of direct acquaintance as follows:

\section{Relational Dogmatism}

If S stands in a relation of direct acquaintance to $p, S$ thereby has immediate and full justification for believing that $p$.

When $\mathrm{S}$ is acquainted with a fact, the fact is said to be "given," or made "manifest," to her. Relational dogmatism - under the heading of "acquaintance theory" - is commonly associated with the British empiricists, particularly Bertrand Rusell (1910-11, 1913). However, the view also has its fair share of contemporary defenders, particularly with respect to perceptual justification. ${ }^{8}$

Relational dogmatism presupposes a relational account of perceptual experience, such as disjunctivism or related conceptions. Disjunctivists hold that perceptual experience is fundamentally a matter of being directly acquainted with an external mind-independent object and perceptible property instances. Perception is thus a success state. Hallucination is not perception but a "mere appearance" (McDOWELL, 1982: 386).

The threat of skepticism has played an important role in motivating the disjunctivist conception of perception. Non-relational accounts of perceptual experience hold that experience involves intermediaries interposing between us and the external world, such as sense data or propositional contents. If, however, perceptual experience directly acquaints us only with intermediaries between us and the external world, then it's hard to see how we can have epistemic access to the external world. On the disjunctivist conception, however, perception directly acquaints us with the external world, which makes it well suited as a justifier of perceptual belief.

The motivation for disjunctivism can also be stated in terms of a response to a skeptical argument. Here is the gist of this type of skeptical argument: on non-relational accounts of perception, perceptual experience does not provide direct conscious access to the external world in virtue of its phenomenology. So, for any perceptual experience $\mathrm{E}$ that provides defeasible justification for thinking that $p$ is the case, there is some alternative skeptical hypothesis $q$, such that $E$ is equally good prima facie, or defeasible, justification for thinking that $q$ is the case. For example, your visual experience of having hands is just as good defeasible justification for thinking that you are (properly manipulated) a brain in a vat (BIV). As $E$ fails to rule out that we are in the skeptical scenario, E does not provide indefeasible justification for the belief that $p$. We can articulate the argument as follows:

\section{Skeptical Argument}

Premise 1: My visual experience of having hands provides at least some degree of justification for thinking that I have hands in virtue of its phenomenology.

Premise 2: My visual experience of having hands provides the same degree of justification for thinking that I have hands in both the actual world and a BIV scenario.

Premise 3: If visual experience of $p$ provides the same degree of justification for thinking that $p$ in both the actual world and a skeptical scenario, it does not provide full justification for thinking that $p$.

Conclusion: My visual experience does not provide full justification for thinking that I have hands. 
Relational dogmatists hold that perceptual experience provides justification for perceptual beliefs in virtue of directly acquainting us with an external-world fact (e.g., McDOWELL, 2008; FISH, 2009a, 2009b). Hallucinations fail to directly acquaint us with any external-world facts, which is to say that the perceptual relation fails to obtain in skeptical scenarios. So, relational dogmatists reject premise (2). ${ }^{9}$ Relational dogmatism is thus in a position to avoid the threat of skepticism for the case of perceptual beliefs.

However, they are not yet off the skeptic's hook. While relational dogmatists can account for how we can have justification for perceptual beliefs and beliefs about a priori truths (e.g., my belief that if I have hands, then I am not a brain in a vat), they cannot account for how we can have justification for external-world beliefs based on ampliative (i.e., inductive or abductive) inference. Or so I will argue.

External-world beliefs based on ampliative inference are commonplace in ordinary life. Here are a few examples: ${ }^{10}$

Ramona's dog never bit any of her visitors in the past.

So, Ramona's dog will not bite her next visitor.

Whenever I ran in the past, my knees hurt afterwards.

So, running makes my knees hurt.

My math professor said that no one has proven Goldbach's conjecture.

So, no one has proven Goldbach's conjecture.

Every time I feed my cat fish, he leaves his food untouched.

So, my cat dislikes fish.
Elvis and Piper have talked about getting married.

Elvis showed a diamond ring to his best friend yesterday.

So, Elvis must be planning to propose to Piper soon.

As a large swath of our external-world beliefs are based on ampliative inference, we can ward off the skeptic only if we can provide a plausible account of ampliative inferential justification. For us to have justification for a belief on the basis of inference, the inference must transmit justification from the premises to the conclusion. Transmission of justification from a single premise to a conclusion must satisfy the following conditions:

\section{Transmission}

Where S competently infers C from P, S's inference transmits justification from $\mathrm{P}$ to $\mathrm{C}$ only if: (i) S has justification for $\mathrm{P}$.

(ii) S has justification that (P supports $C$ ).

(iii) $S$ retains her justifications for $P$ and ( $P$ supports $\mathrm{C}$ ) throughout the inference.

(iv) $\mathrm{S}$ has justification for $\mathrm{C}$ in virtue of (i)-(iii).

Here, I shall take S's inference to be competent just in case it's a valid deductive inference or a moderately strong or strong ampliative inference, which I will take to require that the premises make the conclusion probable. For deductive inferences, (ii) requires that $\mathrm{S}$ have justification for thinking that the premise deductively entails the conclusion. For ampliative inferences, (ii) requires that $S$ have justification for thinking that the truth of the premise makes the truth of the conclusion probable.

Transmission is more demanding than closure. Closure principles for justification require

\footnotetext{
9 Traditional versions of epistemic externalism reject the internalist notion of (non-inferential) justification as inherently linked to the phenomenology of sensory experience. They would reject premise (1). For example, early advocates of reliabilism held that to have a justified belief about the external world is to have a belief formed by a reliable belief-independent process (Goldman, 1979; Nozick, 1981: 264). However, my focus here is not on externalism

10 The first two arguments are inductive, whereas the last three are abductive (or inferences to the best explanation). Abductive arguments have the following underlying form: $O$ is $F$. The best explanation of why $O$ is $F$ is that $O$ is $G$. So, $O$ is $G$. For example, my cat refuses to eat fish. The best explanation of why my cat refuses to eat fish is that she dislikes fish. So, she dislikes fish. Even when the best-explanation premise is left implicit, however, having justification for believing that the remaining premises make the conclusion probable requires having justification for a best-explanation premise. Thus, for intuition to provide justification for thinking that a set of premises support a conclusion in an abductive argument, it will need to provide justification for a best-explanation premise.
} 
that justification be closed across entailment or justified entailment. Closure of justification plays a critical role in multiple-premise transmission. For a multi-premise inference to transmit justification from several or all of its premises to its conclusion, justification must conglomerate with conjunction, which requires closure of justification across entailment by the inference rule of conjunction (BROGAARD, 2013b). E conglomerates with conjunction just in case $E(p) \& E(q) \Rightarrow E(p \& q)$.

If justification is a matter of degree, it fails to agglomerate with conjunction. If, for example, you have justification to a degree of 0.9 for six premises, then (by standard principles of probability) you have justification for their conjunction to a degree of 0.48 . As each of the premises is justified to a high degree, but their conjunction is not, the justification fails to agglomerate with conjunction. When justification fails to agglomerate with conjunction, inference by conjunction fails to transmit justification.

However, the relational dogmatist's notion of justification is not a matter of degree. As the direct quaintance relation either obtains or not, the notion of justification is incorrigible (or infallible). Accordingly, you can only have justification to a degree of 1 . So, the relational dogmatist's notion of justification agglomerates with conjunction. I will set aside this constraint in the remainder of this section. However, we will revisit it when discussing representational dogmatism in the subsequent section.

Before turning to ampliative inferential justification, let's briefly consider deductive inferential justification. Suppose S competently infers the conclusion from the premises in the following the Moore-style argument:

\section{Moore-Style Argument}

(P1) I have hands

(P2) If I have hands, then I am not a BIV.

(C) I am not a BIV.
S's inferences transmits justification from $\mathrm{P}_{1}$ and $\mathrm{P} 2$ to $\mathrm{C}$, only if (i) $\mathrm{S}$ has justification for $\mathrm{P}_{1}$ and $P_{2}$, (ii) $S$ has justification for thinking that $P_{1}$ and $\mathrm{P} 2$ entail $\mathrm{C}$, (iii) $\mathrm{S}$ retains her justifications throughout the inference, (iv) S has justification for $C$ in virtue of (i)-(iii), and $S$ has justification for $C$ in virtue of (i)-(iii).

Philosophers are divided on whether transmission fails for Moore-style arguments. ${ }^{11} \mathrm{~A}$ careful scrutiny of these arguments is beyond the scope of this paper. But a few remarks are in order. Showing that Moore-style arguments fail to rationally overcome doubt about their anti-skeptical conclusion (viz., I'm not a BIV") does not show that they fail to transmit justification, as you can have justification for a proposition, despite doubting it. ${ }^{12}$ However, doubting a proposition prevents you from rationally accepting it. So, Moore-style arguments fail to persuade. But lack of persuasion power is not evidence of transmission failure (PRYOR, 2004).

If transmission should fail for Moore-style arguments, then our justification for the conclusion that we are not a BIV must be independent of our justification for the premises, a requirement that probably cannot be fulfilled. So, if transmission fails, then presumably we cannot come to have inferential justification for the proposition that we are not BIVs. However, most ordinary folks don't ponder whether they are BIVs. So, making this concession to the skeptic is not quite as bad as having to concede that none of our perceptual beliefs about the external world is justified. Ampliative inferential justification presents a more austere challenge for the relational dogmatist, as it requires conceding that we lack justification for everyday beliefs about the external world.

Transmission of justification across ampliative inference is only rarely discussed. One exception is Christopher Tucker (2010), who mentions in passing that ampliative inferences may sometimes allow for transmission. Here is the relevant

11 For arguments for transmission failure for Moore-style arguments, see e.g. Wright (1985, 2002, 2003, 2007), Davies (1998), McLaughlin (2000), and Dretske (2005). For defenses of transmission for Moore-style arguments, see e.g., Pryor (2004, 2012, 2013) and Tucker (2010).

12 E.g., Bergmann (2004), Pryor (2004), Tucker (2010). 
passage:

Consider an inductive inference with one hundred premises of the form "on this occasion the unsuspended pencil fell to the ground." If ninety-nine of the one hundred premises are justified, it seems that those one hundred premises can transmit justification to the belief that the next unsuspended pencil will also fall, despite the fact that one of the premises fails to be justified (TUCKER, 2010, p. 504).

I agree with Tucker that it seems highly plausible that ampliative inferences can sometimes transmit justification. The question here is whether ampliative inferences transmit justification, given the relational dogmatist's notion of justification. Suppose S competently infers that dark clouds and rain are likely to co-occur from one thousand premises of the form "On this occasion, there're dark clouds in the sky, and it's raining":13

\section{Cloud-Rain}

Premise 1: On this occasion, there're dark clouds in the sky, and it's raining.

Premise 2: On this occasion, there're dark clouds in the sky, and it's raining.

Premise 3: On this occasion, there're dark clouds in the sky, and it's raining.

Conclusion: Dark clouds make rain likely.

To establish that S's inference transmits justification from the premises to the conclusion, the relational dogmatist must show that the truth of the premises makes the truth of the conclusion probable. However, this step spells trouble for this variant of dogmatism. It is rather implausible to think that we can be directly aware, or phenomenally acquainted with, the fact that the truth of the premises of ampliative inferences makes the truth of the conclusion probable (RAMSEY, 1926; FUMERTON, 1995, p. 218).

While it is widely agreed that truths about the probabilistic connection between the premises and conclusion of strong ampliative arguments are a posteriori contingencies, it is occasionally argued that such truths (or a subset of them) are a priori truths. ${ }^{14}$

However, the arguments for the a priori status of truths about the probabilistic connection between the premises and conclusion of strong ampliative arguments are deeply problematic. One problem with these arguments is that they proceed on the assumption that we can immediately "see" or "grasp" that the premises make the conclusion probable. However, this observation does not support the claim that we have a priori justification for claims about the connection between the premises and the conclusion of strong ampliative arguments. I can also immediately "see" in a retrieved childhood memory that I am riding a red tricycle, and I can immediately "grasp" that I am tired and hungry. But this does mean that I have a priori justification for the truth of introspective and memory contents.

Another problem with these arguments is that truths about the connection between the premises and conclusion of strong ampliative arguments are contingent truths. Yet these contingent truths are very different from paradigm examples of a priori contingent truths, such as "Jack the Ripper was a serial killer" or "Hesperus is visible in the evening sky." "Jack the Ripper" and "Hesperus" are singular terms introduced by definite descriptions that conceptually guarantee that the predicates " $x$ was a serial killer" and " $x$ is visible in the evening sky" are true of the referents of the singular terms.

If we could have a priori knowledge of claims about probabilistic connections between the premises and conclusion of strong ampliative arguments, this knowledge would be what John Hawthorne (2002) (following EVANS, 1979) calls "deeply contingent a priori knowledge." Hawthorne argues that someone (S) with a body of innate (accurate) principles of what counts as the best explanation in the actual world can have a priori knowledge on the basis of an inference to the

\footnotetext{
13 Nothing hinges on the use of this particular example. Our conclusions are meant to apply to all ampliative inferences (see above for some examples of ampliative inferences).

14 For discussion of historical ancestors of this view (e.g., Keynes, 1921), see Fumerton (1995: ch. 7). More recent sympathizers include BonJour (1998, 2005), Beebe (2009), and Hasan (2017)
} 
best explanation. Where $\mathrm{H}$ is an experiential life history (i.e., a life-long experience) and $T_{1}, T_{2}, \ldots$, $\mathrm{T}_{\mathrm{n}}$ are competing theories about the structure of microphysical reality, S can come to know that, say, $\mathrm{T}_{5}$ is the best explanation of $\mathrm{H}$ and infer the material conditional: $T_{5} \mathrm{H}$. If $\mathrm{T}_{5} \mathrm{H}$ is true, then $\mathrm{S}$ knows that $T_{5} H$. Although $S$ is aware that a host of other theories can explain $\mathrm{H}$ nearly as well as $\mathrm{T}_{5}$, this does not undermine our ascribing knowledge to $\mathrm{S}$, as long as this fact is not salient to us. S's knowledge of $\mathrm{T}_{5} \mathrm{H}$ is deeply contingent a priori knowledge.

While this case is persuasive, it depends on $\mathrm{S}$ possessing a body of innate (accurate) principles of what counts as the best explanation. Ordinary folks, including scientists, acquire the principles needed to make strong inferences to the best explanation on the basis of learning about the structure and regularities of the actual world. So, ordinary folks do not have the capacity for acquiring deeply contingent a priori knowledge. As we lack this capacity, the idea that we can be directly acquainted with probabilistic relations between the premises and the conclusion of strong ampliative arguments is implausible.

But if we cannot be directly acquainted with such truths, then the relational dogmatist must reject transmission for ampliative inferences. Relational dogmatism thus seems to lack the resources to account for the ampliative inferential justification.

It is, of course, open to relational dogmatists to restrict their position to perceptual and a priori justification and adopt some other account of ampliative inferential justification, such as representational dogmatism or reliabilism. But this move would raise the question of why they don't just adopt this alternative account of perceptual justification rather than the acquaintance view. In the next section, I argue that representational dogmatism avoids the difficulties that threaten to undermine relational dogmatism.

\section{The Skeptical Problem and}

\section{Representational Dogmatism}

Representational dogmatism holds that an experience representing that $p$ provides prima facie justification for the belief that $p$ in virtue of phenomenal properties of the experience that make it phenomenally seem that $p$. Since the immediate justifiers of belief are phenomenal seemings and not the underlying experiences, the view can be articulated as follows:

\section{Representational Dogmatism}

If it phenomenally seems to $\mathrm{S}$ that $p$, then, in the absence of defeaters, $S$ thereby has immediate and full justification for believing that $p$.

Before turning to how representational dogmatism avoids the predicaments for relational dogmatism, I should clarify what I mean by "immediate," "full," and "phenomenal seeming." I use "immediate" somewhat differently from how it is sometimes used in discussions of dogmatism (e.g., McGRATH, 2013): a justification E for a belief is immediate just in case $\mathrm{E}$ provides direct justification for the belief, that is, there is no intermediary in virtue of which E provides justification for the belief. E provides full justification for a belief just in case $E$ by itself fully justifies the belief.

The notion of a phenomenal seeming contrasts with that of an epistemic seeming (CHISHOLM, 1957). Phenomenal seemings are evidence-insensitive, whereas epistemic seemings are not (BROGAARD, 2013b, 2018b). To a first approximation, S's seeming that $p$ is evidence-insensitive just in case. S's seeming would persist even if $S$ were in possession of a defeater of the truth of $p$. Suppose it seems to you that congress passed a relief bill on the basis of hearing about it on the news. If the news station later were to inform you that this announcement was mistaken, it would no longer seem to you that congress passed the relief bill. So, you seeming that congress passed a relief bill is evidence-sensitive and therefore epistemic. Now, consider the checker illusion below: 


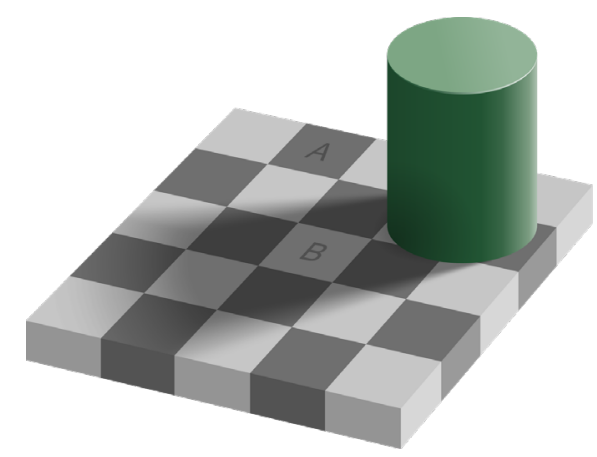

The A square seems darker to me than the B square. This is so in spite of the fact that I know that $A$ and $B$, in fact, have the same shade. As the seeming that $A$ is darker than $B$ persists in spite of the presence of a defeater, the seeming is evidence-insensitive and thus phenomenal.

"Phenomenally looks," "phenomenally sounds," and "phenomenally feels" can replace "phenomenally seems" in relation to visual, auditory, and tactile experiences, respectively (Brogaard, 2018b). But "phenomenally seems" is a more general term, which can also refer to non-sensory phenomenal seemings, such as intuition-based, introspection-based, and memory-based seemings - all of which can play the role of propositional justifier. Here, I will focus on intuition- and memory-based phenomenal seemings.

Memory experiences form the basis of memory-based phenomenal seemings (or memory seemings for short) (BROGAARD, 2017). A memory seeming can be akin to a mental image, a vivid imagination or a vivid dream. But it can also have a more impoverished content as long as its phenomenology is evidence-insensitive. In the absence of a defeater, a memory seeming that $p$ provides full and immediate justification for the belief that $p$.

Intuitions form the basis of intuition-based phenomenally seemings (also sometimes called intellectual seemings). Intuitions are experiences which may have other mental states (e.g., imaginations) as constituents and which may only arise after a brief period of reflection (CHUDNOFF, 2013, 2014b). For example, you may only intuit the validity of the syllogism "All mammals are animals. All giraffes are mammals. Therefore, all giraffes are animals" after briefly reflecting on it. In the absence of a defeater, an intuition-based seeming that $p$ provides full and immediate justification for the belief that $p$.

Let's now turn to how representational dogmatism can respond to the skeptical argument against the possibility of perceptual justification, repeated here from above:

\section{Skeptical Argument}

Premise 1: My visual experience of having hands provides at least some degree of justification for thinking that I have hands in virtue of its phenomenology.

Premise 2: My visual experience of having hands provides the same degree of justification for thinking that I have hands in both the actual world and a BIV scenario.

Premise 3: If visual experience of $p$ provides the same degree of justification for thinking that $p$ in both the actual world and a skeptical scenario, it does not provide full justification for thinking that $p$.

Conclusion: My visual experience does not provide full justification for thinking that I have hands.

According to representational dogmatism, my visual experience of having hands provides prima facie justification for the corresponding belief in virtue of making it phenomenally seem to me that I have hands in both the actual world and the skeptical scenario. This prima facie justification rises to the status of (ultima facie) justifier only in the absence of defeaters, which raises the question of whether the possibility of skepticism prevents my visual seeming that I have hands from rising to the status of ultima facie justifier.

Here is a rough characterization of defeat:15 S's belief that $p$ defeats the justificatory status of S's seeming that $q$ just in case (i) $p$ makes not- $q$ probable, and (ii) $\mathrm{S}$ is justified in believing $p$. For example, your justified belief that most coffee

15 This constraint on defeat is meant to capture both rebutters and undercutters in John Pollock's (1987) sense. Whether a belief that satisfies this constraint actually defeats a given justifier depends on its relative epistemic authority (see Brogaard, 2021). 
shops in your neighborhood use fake flowers for decoration is a potential defeater of the justificatory status of your visual seeming that the flowers in your local coffee shop are real. If you merely doubt $q$ without having any justification for doubting $q$, your doubting $q$ does not defeat the justificatory status of your phenomenal seeming that $q$.

Let's return to the question of whether the possibility of skeptical scenarios can defeat my visual seeming that I have hands. The possibility that I am a BIV clearly cannot defeat my visual seeming that I have hands, as I don't believe that I am a BIV. Admittedly, I do believe it's possible I'm a brain in a vat, but "It's possible that I'm a BIV" does not make "I don't have hands" probable. So, my justified belief that it's possible that I'm a brain in a vat does not defeat my prima facie justification for thinking I have hands. In the absence of defeaters, however, my visual seeming that I have hands provides immediate justification for the corresponding belief in both the actual world and the skeptical scenario. So, my visual experience of having hands provides justification for the corresponding belief in both the actual world and the skeptical scenario. Representational dogmatists can thus reject premise (3) in the skeptical argument.

So, relational and representational dogmatism are both in a position to account for perceptual justification. However, as I will now argue, representational dogmatism fares better than relational dogmatism when it comes to inferential justification for the conclusion of ampliative inferences, such as the cloud-rain inference, repeated here from above:

\section{Cloud-Rain}

Premise 1: On this occasion, there're dark clouds in the sky, and it's raining.

Premise 2: On this occasion, there're dark clouds in the sky, and it's raining.

Premise 3: On this occasion, there're dark clouds in the sky, and it's raining.

Conclusion: Dark clouds make rain likely.
Recall that for multi-premise inferences to transmit justification must agglomerate with conjunction. This requirement may at first seem to create trouble for the representational dogmatist, as "it seems" fails to agglomerate with conjunction. For example, it may seem likely to me that ticket 1 wins, and it may seem likely to me that ticket 2 wins. But it may not seem likely to me that ticket 1 and ticket 2 both win. But it may be argued, if "it seems" fails to agglomerate with conjunction, then representational dogmatists must reject transmission for ampliative inferences, leaving them in the same predicament as the relational dogmatists.

By way of reply, "it seems" as it occurs in "It seems likely to me that ticket 1 wins" is epistemic. However, the seemings that do the justificatory work for the representational dogmatist are phenomenal seemings, not epistemic seemings. As "It phenomenally seems" is not gradable, it agglomerates with conjunction.

The question, then, is whether ampliative inferences satisfy the other constraints on transmission, given representational dogmatism. Let's briefly revisit these constraints:

\section{$\underline{\text { Transmission }}$}

Where S competently infers C from P, S's inference transmits justification from $P$ to $C$ only if:

(i) $S$ has justification for $P$.

(ii) $\mathrm{S}$ has justification that (P supports $\mathrm{C}$ ).

(iii) $S$ retains her justifications for $P$ and ( $P$ supports $C$ ) throughout the inference.

(iv) $\mathrm{S}$ has justification for $\mathrm{C}$ in virtue of (i)-(iii).

As we saw, condition (ii) spells trouble for relational dogmatism, but it doesn't pose a problem for representational dogmatism. While we cannot be directly acquainted with probabilistic facts, it can phenomenally seem to us that such facts obtain. Accordingly, it can phenomenally seem that the truth of the premises makes the truth of the conclusion probable. So, representational dogmatism can account for the possibility of ampliative inferential justification.

If, however, transmission should fail, this would not commit the representational dogmatist to 
skepticism about beliefs about probability claims, like dark clouds make rain likely. Although I do not remember every single occurrence of dark clouds and rain in the past, I remember a constant conjunction of dark clouds and rain in the past. My retrieved memory makes it phenomenally seem that there was constant (or probabilistic) conjunction of dark clouds and rain in the past. This memory-based phenomenal seeming confers immediate and full prima facie justification on my belief that dark clouds make rain likely.

It may be thought that I could not have a memory-based seeming of this sort without having reasoned from beliefs about dark clouds and rain in the past. This, however, is not so. The first time we observe the conjunction of dark clouds and rain, the two experiences are stored separately in memory. When these observations are repeated, however, we form a memory association between dark clouds and rain. Such memory associations are formed when the brain generates new synaptic connections between two types of stored information. As associations are quite different from inferential connections, there is no more of an inference involved in associating dark clouds and rain than there is in associating "doctor" and "nurse." When we retrieve a memory representing constant conjunctions of dark clouds and rain, this results in a memory-based seeming that dark clouds make rain likely. In the absence of defeaters, the seeming that dark clouds make rain likely provides immediate and full justification for the corresponding belief.

Unlike relational dogmatism, representational dogmatism thus has the resources to ward off external-world skepticism, not only about perceptual justification, but also about ampliative inferential justification. ${ }^{16}$

\section{Conclusion}

In this paper, I have distinguished two forms of dogmatism: relational and representational dogmatism. Relational dogmatists hold that a phenomenal state $p$ can provide immediate and full (propositional) justification for $p$ in virtue of directly acquainting us with $p$. Representational dogmatists, by contrast, hold that a phenomenal state $p$ can give us immediate and full (propositional) justification for $p$ in virtue of its phenomenal representation of $p$. I furthermore argued that while both variants of dogmatism can provide an adequate account of perceptual justification, relational dogmatism succumbs to skepticism about ampliative inferential justification.

\section{References}

ALSTON, W. P. Sellars and the Myth of the Given. Philosophy and Phenomenological Research, [S. I.], v. 65 . n. 1, p. 69-86, 2002.

BEEBE, J. The Abductivist Reply to Skepticism. Philosophy and Phenomenological Research, [S. I.], v. 79, n. 3. p. 605-636, 2009.

BERGMANN, M. Epistemic Circularity: Malignant and Benign. Philosophy and Phenomenological Research, [S. I.], n. 69, p. 709-727, 2004.

BONJOUR, L. The Structure of Empirical Knowledge. Cambridge: Harvard University Press, 1985.

BONJOUR, L. In Defense of Pure Reason. Cambridge: Cambridge University Press, 1998.

BONJOUR, L. Toward a Defense of Empirical Foundationalism. In: DEPAUL, M. (ed.). Resurrecting Old-Fashioned Foundationalism. Lanham, MD: Rowman \& Littlefield, 2001. p. 22-38.

BONJOUR, L. A Version of Internalist Foundationalism. In: BONJOUR, L.; SOSA, E. Epistemic Justification: Internalism vs. Externalism, Foundations vs. Virtues. Malden. MA: Blackwell, 2003. p. 3-96.

BONJOUR, L. In Defense of The A Priori. In: STEUP, M.; Sosa, E. (ed.). Contemporary Debates in Epistemology. Malden, MA: Blackwell, 2005. p. 98-105.

BROGAARD, B. Phenomenal Seemings and Sensible Dogmatism. In: C. Tucker (ed.). Seemings and Justification: New Essays on Dogmatism and Phenomenal Conservatism. New York: Oxford University Press, $2013 \mathrm{a}$. p. 270-289.

BROGAARD, B. It's Not What It Seems. A Semantic Account of "Seems" and Seemings. Inquiry, [S. I.], v. 56 , n. 2-3, p. 210-239, 2013b.

BROGAARD, B. Foundationalism. In: BERNECKER, S.; MICHAELIAN, K. (ed.). Routledge Handbook of Philosophy of Memory. Routledge, 2017. p. 296-309.

\footnotetext{
16 For helpful feedback on earlier versions of this paper I am grateful to audiences at the University of lowa and the University of Oslo and participants in a seminar on consciousness and knowledge co-taught with Elijah Chudnoff at the University of Miami in the Spring semester of 2016.
} 
BROGAARD, B. Phenomenal Dogmatism, Seeming Evidentialism and Inferential Justification. In: MCCAIN, K. (ed.), Believing in Accordance with the Evidence: New Essays on Evidentialism. [S. I.]: Synthese Library, 2018a. p. 53-70.

BROGAARD, B. Seeing \& Saying. New York: Oxford University Press, 2018b.

BROGAARD, B. The Rational Roles of Experience. In: ROSENHAGEN, Raja (ed.). Reformed Empiricism and its Prospects. Synthese Library, Springer, 2021.

CHISHOLM, R. M. Perceiving. Princeton: Princeton University Press, 1957.

CHISHOLM, R. M. Theory of Knowledge. Englewood Cliffs, N. J.: Prentice Hall, 1966.

CHUDNOFF, E. Intuition. Oxford: Oxford University Press, 2013

CHUDNOFF, E. (ed.) Review of Tucker Seemings and Justification. Notre Dame Philosophical Reviews, 2014a.

CHUDNOFF, E. The Rational Roles of Intuition. In: BOOTH, A. R.; ROWBOTTOM, D. P. (ed.). Intuitions. Oxford: Oxford University Press, 2014b. p. 9-36.

CHUDNOFF, E. Epistemic Elitism and Other Minds. Philosophy and Phenomenological Research, [S. I.], v. 96, n. 2, p. 276-298, 2018.

DAVIES, M. Externalism, Architecturalism, and Epistemic Warrant. In: WRIGHT, C.; SMITH, B.; MACDONALD, C. (ed.). Knowing Our Own Minds. Oxford: Oxford University Press, 1998. p. 321-361.

DRETSKE, F. The Case against Closure. In: STEUP, M.; SOSA, E. (ed.), Contemporary Debates in Epistemology. Malden, MA: Blackwell, 2005. p. 13-25

EVANS, G. Reference and Contingency. The Monist, IS. I.], v. 62, n. 2, p. 161-189, 1979.

FISH, W. Perception, Hallucination, and Illusion. New York: Oxford University Press, 2009a.

FISH, W. Disjunctivism. Internet Encyclopedia of Philosophy. 200gb. Available at: http://www.iep.utm.edu/ disjunct/\#SH4a.

FUMERTON, R. Metaepistemology and Skepticism. Maryland: Rowman \& Littlefield, 1995

FUMERTON, R. Markie, Speckles, and Classical Foundationalism. Philosophy and Phenomenological Research, [S. I.], v. 79, n. 1, p. 207-212, 2009.

FUMERTON, R. The Prospects for Traditional Internalism. In: COPPENGER, B.; BERGMANN, M. (ed.). Intellectual Assurance: Essays on Traditional Epistemic Internalism, Oxford: Oxford University Press, 2016. p. 239-258.

GOLDMAN, A. What is Justified Belief? In: PAPPAS, G. (ed.). Justification and Knowledge. Dordrecht: Reidel, 1979. p. 1-23

HASAN, A. In: Defense of Rationalism about Abductive Inference. In: POSTON, T.; MCCAIN, K. (ed.). Best Explanations: New Essays on Inference to the Best Explanation. Oxford: Oxford University Press, 2017. p. 150-170.
HAWTHORNE, J. Deeply Contingent A Priori Knowledge. Philosophy and Phenomenological Research, [S. I.], v. 65 , n. 2, p. 247-269. 2002.

HUEMER, M. Skepticism and the Veil of Perception. Lanham (MD): Rowman and Littlefield, 2001.

HUEMER, M. Ethical Intuitionism. Palgrave Macmillan, 2005 .

HUEMER, M. Compassionate Phenomenal Conservatism. Philosophy and Phenomenological Research, IS. l.], n. 74, p. 30-55, 2007.

KEYNES, J. A Treatise on Probability. London: Macmillan, 1921.

LEITE, A. Believing One's Reasons are Good. Synthese [S. I.], n. 161, p. 419-441, 2008.

MCCAIN, K. Evidentialism and Epistemic Justification. Oxford: Routledge, 2014.

MCCAIN, K. Explanationist Aid for Phenomenal Conservatism. Synthese, [S. I.], v. 195, n. 7. p. 3035-3050, 2018.

MCDOWELL, J. Criteria, Defeasibility and Knowledge. Proceedings of the British Academy, [S. I.], n. 68, p. 455479, 1982

MCGRATH, M. Dogmatism, Underminers and Skepticism. Philosophy and Phenomenological Research, IS. l.], v. 86, n. 3, p. 533-562, 2013.

MCGRATH, M. Looks and Perceptual Justification. Philosophy and Phenomenological Research, [S. I.], n. 96, v. 1, p. 110-133, 2018

MCGREW, T. The Foundations of Knowledge, Lanham, MD: Littlefield Adams Books, 1995.

MCGREW, T. A Defense of Classical Foundationalism. In: POJMAN, L. P. (ed.). The Theory of Knowledge: Classical and Contemporary Readings. 2. ed. Belmont, CA/ London: Wadsworth, 1998. p. 224-235.

MCLAUGHLIN, B. Skepticism, Externalism, and Self-Knowledge. Aristotelian Society, [S. I.], Supplementary Volume, n. 74, p. 93-118, 2000.

NOZICK, R. Philosophical Explorations. Cambridge: Harvard University Press, 1991.

POLLOCK, J. Contemporary Theories of Knowledge. Towata, NJ: Rowman, 1986

POLLOCK, J. Defeasible Reasons. Cognitive Science, IS l.], v. 11, n. 4, p. 481-518, 1987

PRYOR, J. The Skeptic and the Dogmatist. Noûs, [S. I.], V. 34, n. 4, p. 517-549, 2000

PRYOR, J. What's Wrong with Moore's Argument? Philosophical Issue [S. I.], n. 14, p. 349-378, 2004

PRYOR, J. When Warrant Transmits. In: COLIVA, A. (ed.) Wittgenstein, Epistemology and Mind: Themes from the Philosophy of Crispin Wright. Oxford: Oxford University Press, 2012. p. 269-303. 
PRYOR, J. Problems for Credulism. In: TUCKER, C. (ed.). Seemings and Justification: New Essays on Dogmatism and Phenomenal Conservatism. New York: Oxford University Press, (2013). p. 89-131.

RAMSEY, W. Prototypes and Conceptual Analysis. Topoi, [S. I.], n. 11, p. 59-70, 1992.

REILAND, I. Experience, Seemings, and Evidence. Pacific Philosophical Quarterly, [S. I.], n. 96, p. 510-534, 2015.

Russell, B. Knowledge by Acquaintance and Knowledge by Description. The Proceedings of the Aristotelian Society, [S. I.], n. 11, p. 209-232, 1910.

RUSSELL, B. Theory of Knowledge: The 1913 Manuscript. E. Eames (ed.). London: Allen and Unwin Ltd., 1984.

SIEGEL, S. The Rationality of Perception. New York: Oxford University Press, 2017.

Silins, N. Basic Justification and the Moorean Response to the Skeptic. Oxford Studies in Epistemology, [S. I.], v. 2. p. 108-140, 2008.

SILINS, N. The Significance of High-Level Content. Philosophical Studies, [S. I.], v. 162, n. 1, p. 13-33, 2013.

STOUTENBURG, G. Traditional Internalism and Foundational Justification. Erkenntnis, [S. I.], v. 85, n. 1, p. 121-138, 2020.

TUCKER, C. When Transmission Fails. Philosophical Review, [S. I.], v. 119, p. 497-529, 2010.

TURRI, J. On the Relationship between Propositional and Doxastic Justification. Philosophy and Phenomenological Research, [S. I.], v. 80, n. 2, p. 312-326, 2010.

WRIGHT, C. Facts and Certainty. Proceedings of the British Academy, [S. I.], v. 71, p. 429-472, 1985.

WRIGHT, C. (Anti-)Sceptics Simple and Subtle: G. E. Moore and John McDowell. Philosophy and Phenomenological Research, [S. I.], v. 65, p. 330-348, 2002.

WRIGHT, C. Some Reflections on the Acquisition of Warrant by Inference. In: NUCCETELLI, S. (ed.), New Essays on Semantic Externalism and Self-Knowledge. Cambridge, Mass.: MIT Press, 2003. p. 57-77.

WRIGHT, C. Perils of Dogmatism. In: NUCCETELLI, S. (ed.). Themes from G. E. Moore: New Essays in Epistemology and Ethics. Oxford: Oxford University Press, 2007. p. 25-48.

\section{Berit Brogaard}

Professor and Cooper Fellow, University of Miami.

\section{Mailing address}

\section{Berit Brogaard}

Department of Philosophy

University of Miami

Coral Gables, FL 33124, USA

Os textos deste artigo foram conferidos pela Poá Comunicação e submetidos para validação do autor antes da publicação. 